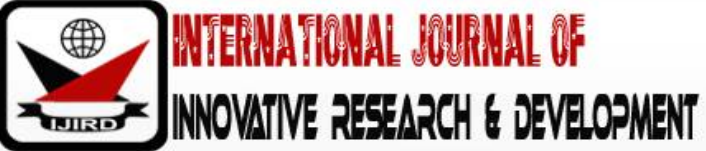

ISSN 2278-0211 (Online)

\section{Determinant Factors of Rural Youth Participation in Agricultural Development Programme at Majalengka District, Indonesia}

\author{
Dr. Lukman Effendy \\ Lecturer, Department Name of Agriculture, \\ Bogor Agriculture Development Polytechnic, Indonesia \\ Dr. Yoyon Haryanto \\ Lecturer, Department of Agriculture, \\ Center for Agricultural Education, Indonesia
}

\begin{abstract}
:
Research on rural youth's participation in agricultural development especially in Majalengka is limited. This study aims to: (1) describe existing youth participation rate, (2) analyse factors determine youth participation in agricultural development, and (3) formulate strategies to increase youth participation in agricultural development. A survey was conducted using a closed questionnaire taken from 90 respondents, on which they selected by using Slovin formula. The respondents were selected from 726 youth populations in four sub-districts. The research findings are: (1) youth participation in agricultural development is in medium category with the average score 2.23. The independent variables (personal characteristics, external support, and motivation) are also in the moderate category. (2) Those independents variables contribute significantly $(p \leq 0.01)$ to youth participation, with coefficients of influence for personal characteristics, external support, and motivation are $-0.014,0.343$, and 0.651 respectively. (3) strategies to increase youth participation are to maintain and encourage motivation through enhancing personal capacity and external support by (a) facilitating youth in education and training, encouraging them in youth organizations or farmer groups; (b) optimizing farmer groups' support in empowering human and natural resources; and (c) maintaining participation's due to the desire of being better known by the surrounding community, opportunity to build cooperation, and maintaining unconditional motive in participating.
\end{abstract}

Keywords: Participation, youth, agricultural development

\section{Introduction}

Agricultural development is facing problems and challenges, such as the low implementation of innovative technology, low farmers' income, massively decreased of productive farmlands, and diminishing passion of farmers working in the agricultural sector. On the other hand, the diminished passion does not in-line with the increased number of annual population growth. Data from National Statistical Bureau (2013) has shown that $61 \%$ farmers aged over 45 years old, $1 \%$ between $15-24$ years old, $12 \%$ in a range age of $25-34$ years, and $26 \%$ between $35-44$ years old. Also, Coalition community for food sovereignty (KRKP, 2015) also declare that $96.45 \%$ of crop farmers aged more than 30 years old. However, $70 \%$ of that age does not have passionfor farming. This condition indicates that youngster has less passion for becoming a farmer. KRKP also mentioned that only $54 \%$ of farmers' son is willing to continue parents' job in crop and $36.7 \%$ in horticulture farmers. This condition indicates that farmer-regeneration crisis is happening in Indonesia.

There are many reasons for the young generation to work in the agricultural sector. This sector is unprestigious for them because farmers are connoted with peasant and poor. Farmers have poor education, as $73.97 \%$ of them only finished secondary school (Andreeyan, 2014). Also, the youngster has never been taught by their parents (as this is confirmed by $64 \%$ youth in crop and $86.7 \%$ in horticulture). Other reasons are (Juwita, 2015) (1) small scale of farming, (2) limited access capital, (3) lack of technology, (4) high affected by climate, (5) limited selling coverage, (6) limited use of post-harvest technology which impact on low crop quality, (7) high land conversion, (8) high price and limited availability of fertilizer, (9) limited seed available, (10) farming is high depend on family labor.

The successes and continuity of agricultural development highly depend on youth generation. According to Law Number 40/2009, A youth range age is between 15-30 years. A number of youth is around 25\% (62.4 million) of the total number of Indonesia population (BPS, 2017). However, those potential numbers do not equal with their contribution to actively participate working in the agriculture sector. Also, youth passion for working in the agricultural sector is diminishing every year. Over the period of August 2015-2016, the population working in agricultural sector decrease from 37.75 million (32.88\%) to 35.77 million (31.90\%) (BPS, 2017). Kelompok Sanggar Seni Panghegar (2010) mentioned the 
weaknesses of current development are: (1) exclusiveness of program that makes less harmonies between related program, (2) ad-hoc (temporary) program which makes it less sustain, (3) participation that tends to be mobilized and does not based on self-awareness, (4) in-kind support that leads to high dependence on external support and less selfdependence and creativity, (5) increased community capacity does not support by increased capacity of local government.

There are few research conducted to identify the contribution of youth generation in agriculture development. Therefore, this research will contribute to study on that issue, focus in Majalengka District, West Java. In specific, the focus of this study is: (1) describe to what extent the participation of youth in agricultural development in Majalengka District, (2) what factors determine youth participation in agricultural development in Majalengka District? (3)how does the youth participation model of agricultural development in Majalengka District?

\section{Research Methodology}

\subsection{Research Framework: Participation}

Factors determine youth participation's influence in agricultural development are: (1) individual characteristic: age, education level, organization experience; (2) external support: group support, human resource availability, natural resources availability, extension, infrastructure, (3) motivation: social relation, appreciation, willingness to achievement, training opportunity, and dedication to parents. Meanwhile, participation (Y) consists of a contributionon formulation agricultural development regulation, agriculture entrepreneur, participation in farmer empowerment, active participation in farmer advocation. Those factors, partially or in-group, is predicted influence youth participation in agriculture development as the following scheme:

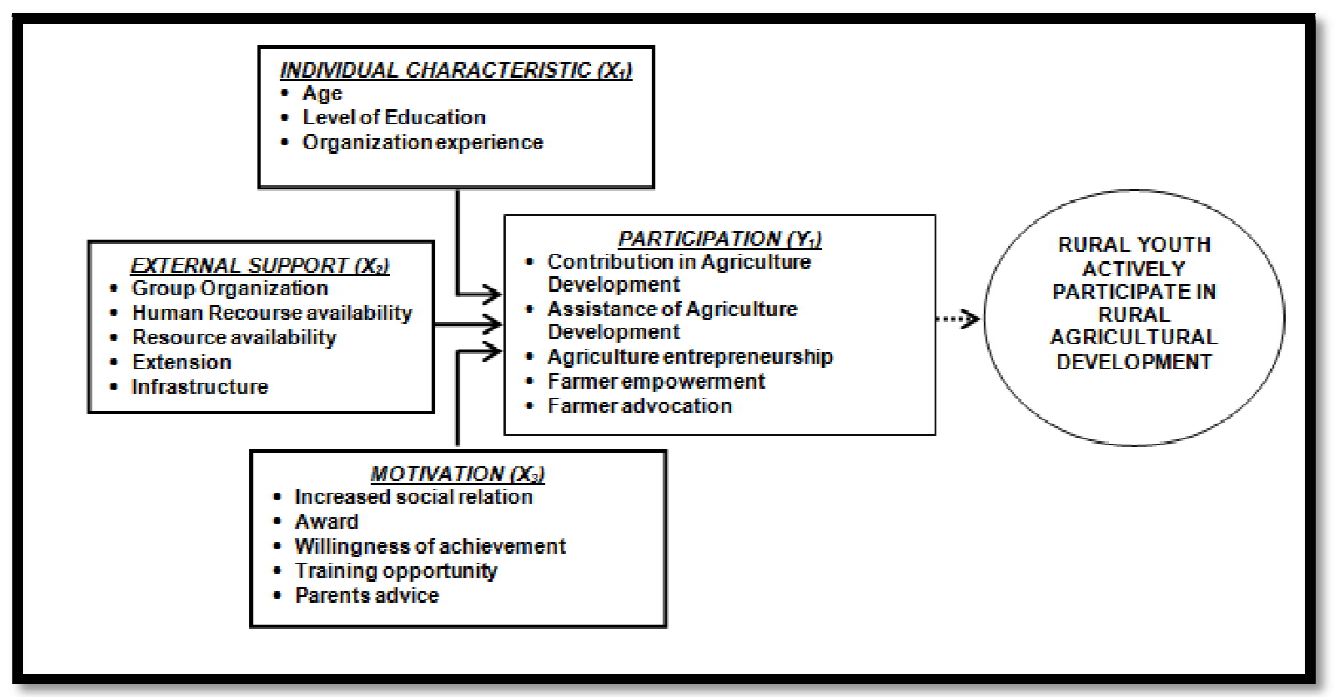

Figure 1: Research Framework

\subsection{Population and Sampling}

Population on this research was youth involved in the ruralorganisation of four sub-districts in Majalengka, West Java. The total population is 726 youth (Table 5). A number ofsampleswere selected by using Slovin (Djarwanto. 1996) as follow:

$$
\mathrm{n}=\frac{\mathrm{N}}{1+\mathrm{N}(e)^{2}}
$$

\section{Explanation:}

$\mathrm{n}=$ number of samples

$\mathrm{N}=$ number of populations

$e=$ sampling error $(10 \%)$

According to that formula, the minimum sample was 88. Then this research selected 90 respondents on which it was selected proportionally from those sub-districts as follow: Majalengka sub-district 21 respondents, Panyingkiran subdistrict 17 respondents, Kadipaten sub-district 31 respondents, Dawuan sub-district 21 respondents. Further, the respondentin each rural was selected by using simple random sampling proportional according to a number ofyouths in each sub-district as in the following table. 


\begin{tabular}{|c|c|c|c|c|}
\hline No & Sub-district & Village & Population & Respondent/Sampling \\
\hline \multirow[t]{6}{*}{1} & Majalengka & Munjul & 30 & 4 \\
\hline & & BabakanJawa & 50 & 6 \\
\hline & & Sindangkasih & 47 & 6 \\
\hline & & Tarikolot & 19 & 2 \\
\hline & & 5. Cikasarung & 24 & 3 \\
\hline & & Sub-Total (1) & 170 & 21 \\
\hline \multirow[t]{6}{*}{2} & Panyingkiran & 1. $\quad$ Cijurey & 18 & 2 \\
\hline & & Pasirmuncang & 27 & 3 \\
\hline & & Bantrangsana & 12 & 2 \\
\hline & & Panyingkiran & 32 & 4 \\
\hline & & 5. Karyamukti & 45 & 6 \\
\hline & & Sub-Total (2) & 134 & 17 \\
\hline \multirow[t]{6}{*}{3} & Kadipaten & 1. $\quad$ Heuleut & 52 & 6 \\
\hline & & BabakanAnyar & 16 & 2 \\
\hline & & Karangsambung & 61 & 8 \\
\hline & & Liangjulang & 80 & 10 \\
\hline & & 5. Pagandon & 39 & 5 \\
\hline & & Sub-Total (3) & 248 & 31 \\
\hline \multirow[t]{7}{*}{4} & Dawuan & 1. KarangAnyar & 20 & 2 \\
\hline & & Salawana & 26 & 3 \\
\hline & & Gandu & 40 & 5 \\
\hline & & Genteng & 40 & 5 \\
\hline & & 5. Balida/Bojongcideres & 48 & 6 \\
\hline & & Sub-Total (4) & 174 & 21 \\
\hline & & Total & 726 & 90 \\
\hline
\end{tabular}

Table 1: Number of the Respondent in Each Village and Sub-District

Definition operational of the variable as follow:

- Characteristic respondent (X1) is a personal characteristic of rural youth, consist of age, level of education, experience, level of cosmopolitan

- External supports (X2) relates to facility support, consist of group organisation, Resource support, Extension support, and government regulation

- Motivation (X3) is encouragement or desire comes from inside or outside respondents to do something, consist of: increased of social relation, getting an achievement, willingness for an achievement, and getting power

- Youth participation is youth opportunity in agricultural development, consist of their contribution in formulating development policy, their contribution in entrepreneurship, their contribution in empowerment or extension, and their contribution in advocating

- A youth is male or female age 25-40 years old and join in a youthorganisation in a Village

- Type of youth organisation: Komite Nasional Pemuda Indonesia (KNPI), KarangTaruna, other Youth Group Organisation in a village where the respondent lives

Detail Variables, Indicators, and Parameters for this study as in Annex 1.

\subsection{Data Collection Technique}

Data was collected through a direct interview by using a questionnaire, on which it is tested its validity and reliability. The validity of the questionnaire is derived from the concept used in this study. The validity was focused on: (1) Did substantial measurement reflect the content of the questionnaire, (2) did information collected in-line with the conceptbeing used. The validity was tested use jury opinion. Further, questionnaire's reliability refers to its capacity to measure phenomena or response consistently. According to Kerlinger (2004), three conditions to measure reliability are stability, accuracy, validity. The reliability was measured through (1) testing instruments to 10 respondents in subdistricts Cibungbulang, on which they have similar characteristics with as the real respondents; (2) Reliability test used coefficient Cronbach alpha (Marzuki dan Burhan, 2000), with score 0,968. This score reflected that the instrument is reliable for further data collection.

Further, a secondary data was collected from reports and documents available in village and sub-district office. The data collections then were followed by in-depth interview through Focus Group Discussion (FGD). The whole data collection process was done by extension officers in sub-district, on which they were trained as an enumerator.

\subsection{Data Analysis}

Data wereanalysed by using descriptive and statistic inferential through regression using SPSS 1.8 series. Analysis statistic descriptive aims to describe youth participation in agriculture development. Meanwhile, the contribution of dependent variables was analysed by using multiple regression analysis. 


\section{Result and Discussion}

\subsection{Respondents Characteristic}

As shown in Table 2, the highest age of respondents ranged from 27-29 years old (32.2\%). Meanwhile, most respondents (32.2\%) aged 27-29 years old. According to Law Number 40/2009, these ages are the real youth. This agerange is physically and mentally potential to participate in agriculture development. Result also shows that mostly respondent has education in High School or diploma. This education status helps youth to participate. This result in-line with previous research by Sudana and Kasdi (2015) that actor participate higher if their age younger.

Further, length of education ranges from 12-17 years old (68.8\%). Meanwhile, about 55.6\% attended training under seven days. In addition, they had organisation experience also less than seven days (41.1\%). This result is slightly different with their experience in training experience that mostly respondent $\mathrm{s}$ (55.6\%) had attended training less than one week (7 days). This condition was not supported youth training and experience. Therefore, it is required an opportunity for gaining youth's experience either in training or youth organisation. These findings related to research by Bahua (2010) that work-experience have high relevance with extension daily performance. Sudana and Subagyo (2012) also stated that farming experience is highly influenced adoption rate, besides age and education level. Also, Puji and Tin (2016) mentioned that internal characteristic such as farming experience, land ownership, and cosmopolitan are highly related to farmer participation. These results show that youth characteristic (age, level of education, training and organisation experience) influence their participation. To sum up, the youth participation in agricultural development can be done through improved their capacity in training and opportunity to actively participate in your organization.

\begin{tabular}{|c|c|c|c|}
\hline No & Indicators & Number of People & Percentage (\%) \\
\hline 1 & $\begin{array}{c}\underline{\text { Age }} \\
17 \text { yrs. }-24 \text { yrs } \\
25 \text { yrs }-26 \text { yrs } \\
27 \text { yrs }-29 \text { yrs } \\
\geq \geq 30 \text { yrs }\end{array}$ & $\begin{array}{l}20 \\
15 \\
29 \\
26\end{array}$ & $\begin{array}{l}22.2 \\
16.7 \\
32.2 \\
28.9\end{array}$ \\
\hline 2 & $\begin{array}{c}\text { Length of Education } \\
\leq 6 \mathrm{yrs} . \\
9 \mathrm{yrs}-11 \text { yrs. } \\
12 \text { yrs. }-17 \text { yrs. } \\
\geq 18 \text { yrs. }\end{array}$ & $\begin{array}{c}5 \\
23 \\
62 \\
-\end{array}$ & $\begin{array}{c}5.6 \\
25.6 \\
68.8 \\
00.0\end{array}$ \\
\hline 3 & $\begin{array}{c}\frac{\text { Length of Training }}{<7 \text { days }} \\
7 \quad 13 \text { days } \\
14 \text { days }-48 \text { days } \\
>48 \text { days }\end{array}$ & $\begin{array}{l}50 \\
24 \\
16 \\
-\end{array}$ & $\begin{array}{l}55.6 \\
26.7 \\
17.7 \\
00.0\end{array}$ \\
\hline 4 & $\begin{array}{c}\frac{\text { Length of Experience }}{<12 \text { months }} \\
13 \text { months }-21 \text { months } \\
22 \text { months }-24 \text { months } \\
>24 \text { months }\end{array}$ & $\begin{array}{c}37 \\
2 \\
16 \\
35\end{array}$ & $\begin{array}{c}41.1 \\
2.2 \\
17.8 \\
38.9\end{array}$ \\
\hline
\end{tabular}

Table 2: Respondents' Characteristic by Age, Education, Training, and Experience Source: Primary Data

\subsection{External Support}

Data in Table 3 shows that the mean of external support variable is 2,51. This score is in the medium category. The highest score was obtained from 'group existence $(2,61)$ '. Meanwhile, the lowest score was obtained in 'human resource available' and 'natural resources', with each score is 2,37 and 2,54 respectively. Detail of the score as the following table.

\begin{tabular}{|c|c|c|}
\hline No & Indicator & Average Score \\
\hline 1 & Support for group existence & 2.61 \\
\hline 2 & Human and natural resource availability & 2.37 \\
\hline 3 & Infrastructure availability & 2.54 \\
\hline
\end{tabular}

Table 3: The Average Score of External Support

Source: Primary Data

\subsection{Motivation}

Data in table 4 shows that motivation has mean score 2.39 , which is a medium category. Meanwhile, the average score for each indicatorranges from 2.10 - 2.85. The highest score, 2.85, is 'willingness to popular in their areas'. While the lowest score, 2,10 , is 'willingness to get award'. These results indicate that youth tend to be well-known by the community, without expecting any return. 


\begin{tabular}{|c|c|c|}
\hline No & Indicators & Average score \\
\hline 1 & Known in their community & 2.85 \\
\hline 2 & Opportunity to partnership & 2.57 \\
\hline 3 & Getting reward from their village & 2.10 \\
\hline 4 & Getting education opportunity & 2.51 \\
\hline 5 & Accomplishment & 2.11 \\
\hline 6 & Accomplishment in farming & 2.29 \\
\hline 7 & Respectful & 2.43 \\
\hline 8 & No other choice & 2.29 \\
\hline
\end{tabular}

Table 4: Average Motivation Score Source: Primary Data

\subsection{Youth Participation}

According to the result, the mean score of participation is 2,23 , that is a medium category. The average score for each indicatorranges from 2.08-2.36. The highest score is 2.36, about 'youth participation in helping extension activities'. Meanwhile, the lowest score is 2.08, 'expansion of the agricultural business'. Detail of the scores is as the following table:

\begin{tabular}{|c|c|c|}
\hline No & Indicators & Average score \\
\hline 1 & Written advice & 2.18 \\
\hline 2 & Assistance of agricultural development program & 2.18 \\
\hline 3 & Developing agricultural trade & 2.08 \\
\hline 4 & Helping extension & 2.36 \\
\hline 5 & Program's submission & 2.34 \\
\hline
\end{tabular}

Table 5: The Average Score of Participation

Source: Primary Data

The overall analysis of the variables shows that youth participation in agricultural development in selected subdistrict is in the medium category, with the average score 2.23 (the lowest score amongst those mentioned). Meanwhile, the external support has the highest average score, 2.51 (medium category). Further, motivation and personal characteristic have average score 2.40 and 2.24 (medium category). Detail of the score as in the following table

\begin{tabular}{|c|c|c|}
\hline No & Variables & Average score \\
\hline 1 & Participation $(\mathrm{Y})$ & 2.23 \\
\hline 2 & Characteristic Respondents $\left(\mathrm{X}_{1}\right)$ & 2.22 \\
\hline 3 & External Supports $\left(\mathrm{X}_{2}\right)$ & 2.51 \\
\hline 4 & Motivation $\left(\mathrm{X}_{3}\right)$ & 2.40 \\
\hline
\end{tabular}

Table 6: Average Score for Each Variable

Source: Primary Data

\subsection{Response of Personal Characteristic, External Support and Motivation on Youth Participation}

To determine extent response of independent variable to youth participation, data will be analyzed by using multiple regression analysis. Model of equation to be used is: $Y=a+b_{1} \cdot X_{1}+b_{2} \cdot X_{2}+b_{3} \cdot X_{3}$, on which:

- $\mathrm{Y}=$ dependent variables (youth participation)

- $\mathrm{X}_{1}=$ independent variables 1 (personal characteristic)

- $\mathrm{X}_{2}=$ independentvariebles2 (external support)

- $\mathrm{X}_{3}=$ independent variables3 (motivation)

- $\mathrm{a}=$ constant

- $\mathrm{b}=$ coefficient of regression

Result of the analysis shows that influence of personal characteristic, external support, and motivation, to youth participation in agricultural development are $\mathrm{Y}=(-0.153)+(-0.014) \mathrm{X}_{1}+(0.343) \mathrm{X}_{2}+(0.651) \mathrm{X}_{3}$ with $\mathrm{p} \leq 001$. This result means that personal characteristic (X1) give contribution -0.014 , external support give contribution 0.343 , and 0.651 in motivation.

\subsubsection{The Response of Personal Characteristic to Youth Participation}

The regression analysis shows that personal characteristic gives a negative response to youth participation (0.014). Although this coefficient relatively small, it can increase youth participation if aspect in characteristic variables increased, especially in increased capacity and training experiences.

\subsubsection{The Response of External Support to Youth Participation}

The result from regression analysis shows that the external support has a real impact $(\mathrm{p} \leq 0.01)$ on youth participation, with a coefficient of influence is 0.343 . The dominant external supports are determined by group existence, 
human resource availability, and infrastructure availability. These findings are pointing to the clue that the higher the support from farmer group, the higher youth participation in agricultural development. These findings are in-line with research by Effendy (2016) that extension and farmers organisation influence farmers in integrated crop management's adoption. The highest influence comes from farmer's group. This result in line with research findings from Nuret al (2012) that participation depends on internal factors that consist of community support and local infrastructure, on which they have scored 2,41 and 2,42 respectively. To sum up, the youth participation in agricultural development can be increased through external support, consist of improved farmers' group contribution, improved human resource capability, and utilisation of natural resource and other local infrastructure facilities.

\subsubsection{The Response of Motivation to Youth Participation}

The result show that variable motivation has a positive impact $(\mathrm{P}<-0.01)$ to youth participation in agricultural development, with value 0.651 . This value indicates that the higher rate of youth participates, the higher they participate in agricultural development. This result supports previous research by Effendy (2009) that factors motivate farmers in developing integrated pest control are a willingness to enlarge social relation. This result concludes that youth participation in agricultural development can be identified from the extent of youth motivation. This motivation can be improved by giving them the opportunity to express themselves in the community through cooperation activities.

\subsubsection{The Response of Personal Characteristic, External Support, Motivation, to Youth Participation}

The result from regression analysis shows that personal characteristic, external support and motivation have a clear impact $(\mathrm{p} \leq 0.05)$ of youth participation in agricultural development. This result shows that if personal characteristic (X1), external support (X2), motivation (X3) have zero (0) score, then youth participation (Y) will have negative score 0.153. Further, coefficient score b1 is -0.014 means that if external support (X2) and motivation (X3) are constant, so that each improved personal characteristic (X1) for one unit, will decrease youth participation 0.014. Further, a score of coefficients b2 is 0.343 , on which this score entails in external support (X2). This score has meant that if motivation (X3) and personal characteristic (X1) is constant so that each increased one of external support (X2) will increased youth participation (Y) by 0.343 . Moreover, the increased one score of motivation (X3) will increase youth participation (Y) by $0.651(=\mathrm{b} 3)$, if there is a constant (X1) and (X3).

Therefore, youth participation will decrease if X1 increase and the participation will improve if external support and motivation increase. Thus, personal characteristic has to be improved through training and education. Thus, motivations have higher contribution to improve participation than external support.

\subsection{The Model and Result Implementation}

Supporting youth in personal capacity and external support are ways to improve their participation. The supports such as: (a) facilitating youth in training and education and support them actively participate in youth organization and any similar organization; (b) optimizing and maximizing farmer group support in human resource empowerment and local natural resources, (c) maintaining participation's spirit, opportunity to build relationship, and maintaining unconditional motive to participate.

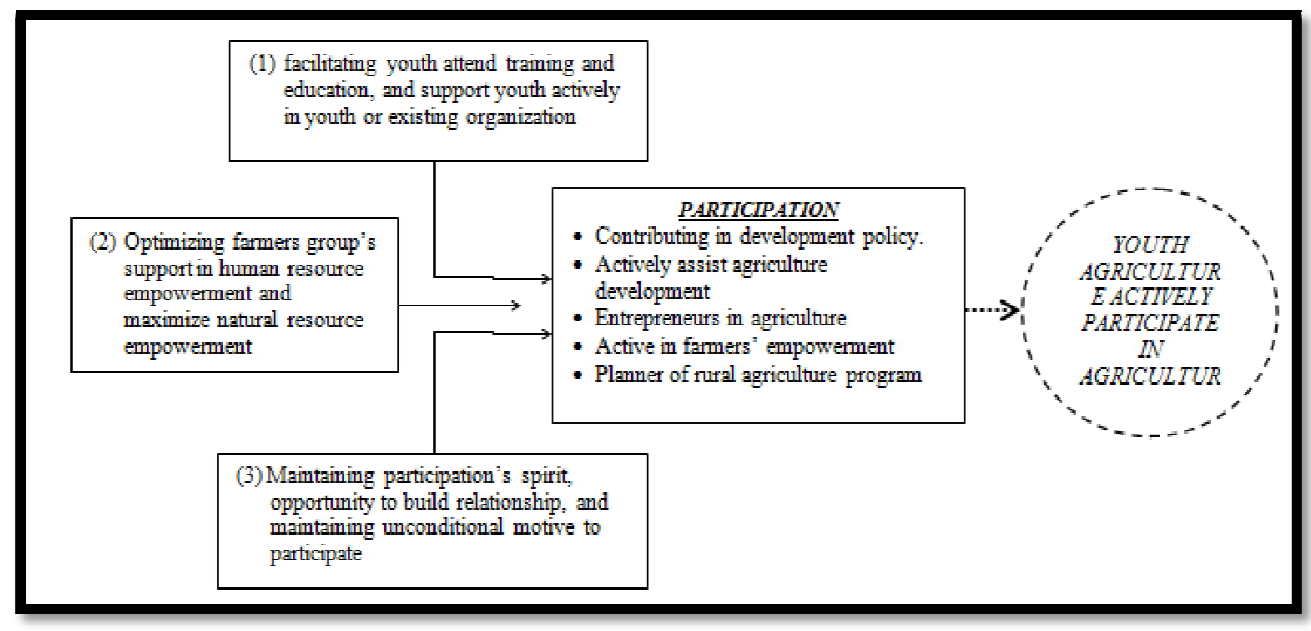

Figure 2: The Result of the Research

The above figure shows that to increase youth participation in agricultural development actions can be created in: (1) their personal characteristics through education and training and support them to actively participate in youth and or existing organization; (2) external support through optimizing farmers' group, human resource's empowerment, and natural resources' empowerment, (3) their motivation through cooperation's opportunity, and maintaining unconditional motive to participate.

\section{Conclusion}

The results of this study conclude: (1) Youth participation in agricultural development in Majalengka District is in the moderate category, with average score 2.23. All independents variables (personal characteristics, external support, 
motivation) also in the moderate category, (2) Each independents variable has a clear contribution ( $\mathrm{p} \leq 0.01)$ to youth participation in agricultural development. Response coefficients for each variable are: personal characteristic, -0.014, external support 0.343 , and motivation 0.651 , (3) The model of increasing youth participation in agricultural development in Majalengka Regency, starting with increasing youth capacity through training, then optimizing group support by developing group functions as a vehicle for collaboration.

\section{Recommendation}

This study imposes some recommendations for further study as follow: (1) The resultof the negative contribution (b1) of youth's characteristic needs further study, (2) It is required to do a similar study with enlarged coverage areas, as this only cover 26 sub-districts.

\section{Acknowledgmentt}

With the completion of this research, the author would like to express his gratitude, especially to lecturer colleagues of the Sustainable Agriculture Extension Study Program for their encouragement and assistance to complete this research. Likewise, to the head of Unit of Research and Community Service (UPPM), thank you for your help in carrying out this research. To the Director of the Bogor Agricultural Development Polytechnic, the author also thanked for the opportunity and support that has been given.

\section{References}

i. Anonymous. 2010. Identifikasi Faktor Penghambat Pembangunan. Kelompok Sanggar Seni Majalengka. http://suaramajalengka.blogspot.co.id/2011/02/gali-potensi-sumber-daya-pemuda.html. Accessed 14 Sept 2017 09.31

ii. Accel-Team 'Employee motivation: Theory and practice'. Available in http://www.accel-team.com. [Accessed 8 Mei 2017]

iii. Adi, IsbandiRukminto. 2001. Pemberdayaan, Pengembangan Masyarakat dan Intervensi Komunitas. Jakarta: LembagaPenelitian FE-UI.

iv. Agustin. Merry dan Tjiktjik Rahayu.2016. Partisipasi Masyarakat dalam Perencanaan Pembangunan Desa Melalui Musrenbang (Studi Kasus Pada Pembangunan Japordes Desa Tunggunjagir Kecamatan Mantup Kabupaten Lamongan). Available in http://repository.ipb.ac.id/jspui/bitstream/1/I16yes.[Accesed on 5Juni 2017, 11.05 WIB].

v. Ajuan, Ritonga, Erlina, and Supriadi. 2016. Analisis Peran Pemuda Terhadap Pembangunan Pertanian Olahan Pangan Berkelanjutan di Kabupaten Labuhan Batu Utara. Available in http://download.portalgaruda.org/article.php?article [Accesed on 1`Maret 2017]

vi. Andreeyan, Rizal. 2014. Studi Partisipasi Masyarakat dalam Pelaksanaan Pembangunan di Kelurahan Sambutan Kec. Sambutan Kota Samarinda. Jurnal Administrasi Negara 2(4) 1938-1951, 2014

vii. Angell, P. 1967. The Growth of Transnational Participations. Jurnal of Social. Available on onlinelibrary. wiley.com [Accesed on 6 Maret 2017]

viii. Astuti, Sri. 2015. Peran Pemuda dalam Pembangunan Pertanian. Available on http://sriastutipenyuluh.blogspot.co.id/2012/10/peran-pemuda-dalam-pembangunan-pertanian.html. [Accesed on 1 Maret 2017]

ix. Azwar. 2003. Sikap Manusia: Teori dan Pengukurannya. Yogyakarta: (ID). Liberty Press.

x. BagongSuyanto. 2017. Krisis Regenerasi Petani Muda. Available on https://kompas.id/baca/opini/2017/09/18/krisis-regenerasi-petani-muda/[Accesed on 14 - 11 - 2017]

xi. Bahua M.I. 2010. Faktor-faktor yang Mempengaruhi Kinerja Penyuluh Pertanian dan Dampaknya pada Perilaku Petani Jagung di Provinsi Gorontalo. [Disertasi]. Bogor: Sekolah PascasarjanaInstitutPertanian Bogor

xii. BadanPusatStatistik. 2013. Badan Pusat StatsitikProvinsiJawa Barat.

xiii. BadanPusatStatistik. 2015. BadanPusatStatisti: BPS

xiv. BadanPusatStatistik. 2016. Kabupaten Majalengka dalam Angka 2016. Badan Pusat Statistik Kab. Majalengka: BPS

xv. BadanPusatStatistik. 2017. BadanPusatStatistik: BPS

xvi. Bryan, Caroline. \& Louise G White. 1982. Managing Development in Thirtd Word. Colorado: Westview Press, Boulder.

xvii. Bustang. M.A.M. 2014. Urgensi Regenerasi SDM Pertanian dalam Upaya Mencapai Kedaulatan Pangan. Journal of

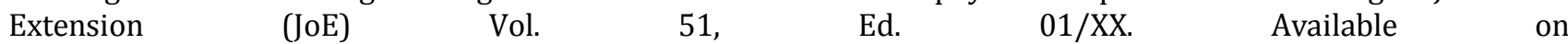
http://perpustakaan.bappenas.go.id/lontar/file?file=digital/139106-[Konten]

Urgensi\%20Regenerasi\%20SDM\%20Pertanian.pdf[Accessed 14 - 11 - 2017]

xviii. Cohen, J.M. and Uphoff, N.T. 1977. Rural Development Participation: Concept and Measures for Project. Cornel University. New York. Available on https//www.researchgate.net. [Accessed 6 Maret 2017)

xix. Dale A.T. 1986. Motivation of Personnel. Fact on File Publications. New York.

xx. Davis K, Newstrom J.W.1996. Perilaku dalam Organisasi, Edisi Ketujuh. Jakarta: Penerbit Erlangga.

xxi. Djarwanto. 1996. Mengenal Beberapa Uji Statistik dalam Penelitian. Yogyakarta: Liberty.

xxii. Effendy, Lukman. 2009. Kinerja Petani Pemandu dalam Pengembangan PHT dan Dampaknya pada Perilaku Petani di Jawa Barat. Disertasi Doktor, Bogor: Sekolah Pascasarjana, IPB.

xxiii. Effendy, Lukman. 2016. Model Peningkatan Kapasitas Penyuluh dalam Pemanfaatan Informasi Iklim di Kabupaten Indramayu dengan Pendekatan Analisis Keberlanjutan. Jurnal Informasi Pertanian. Vo.25 No.1 Maret 2016 
xxiv. Effendy, Lukman. 2017. Peran Kelembagaan dan Atribut Inovasi dalam Adopsi Teknologi Pengelolaan Tanaman Terpadu Padi Sawah di Kabupaten Bandung Barat dan Sumedang. Jurnal Penyuluhan Pertanian Vol. 12 No.1 Mei 2017

xxv. Henryk. Stepanus. 2013. Partisipasi Masyarakat dalam Pembangunan di Kelurahan Sungai Keledang Kecamatan Samarinda Seberang Kota Samarinda. Available onejournal.ip.fisip-unmul.ac.id/side.wp/content/upload/2013. [Accessed 6 Juni 2017, 9.30 WIB]

xxvi. Herwin, A.D. 2016. Regenerasi Petani Masalah Bangsa yang Mematikan. Available on https://kompas.id/baca/opini/2017/09/18/krisis-regenerasi-petani-muda/[Accessed 14 - $11-2017$

xxvii. Hersey P, Blanchard K.H. 1982. Management of Organizational Behavior. Utilizing Human Resources (4thed). Jakarta:Terjemahan, PenerbitErlangga.

xxviii. Juwita,

Silvia.

PeranGenerasiMudadanPengembanganPertanianBerkelanjutanlog.umy.ac.id/rahmanafaizah/tugas-tik/perangenerasi-muda-dan-pengembangan-pertanian-berkelanjutan-2. [Accessed 1 Maret 2017]

xxix. Kali, Agustinus. 2011. Analisis Partisipasi Masyarakat terhadap Perencanaan dan Pembangunan PLTMH di Panike Pombewa Kec. Biromoru Kab. Sigi. Majalah Ilmiah (Mektek) XIII, No.3.

xxx. Kerlinger F. N. 2004. Asas-asasPenelitian Behavioral. Yogyakarta: Gajah Mada University Press.

xxxi. Koalisi Rakyat untukKedaulatan Pangan. $2015 . \quad$ Regenerasi Tersediapadahttp://images.agriprofocus.nl/upload/2015_KRKP_Laporan_Kajian_Regenerasi_Petani1466659556.pd $f[$ Accessed $14-11$ - 2017]

xxxii. LembagaIlmuPengetahuan Indonesia (LIPI). 2017. Indonesia Krisis Regenerasi Petani Muda. Available on http://lipi.go.id/lipimedia/Indonesia-Krisis-Regenerasi-Petani-Muda/18098[Accessed 14 - 11 - 2017]

xxxiii. Marzuki G. dan Burhan N. 2000. Statisti Terapan untuk Ilmu-IlmuSosial. Yogyakarta: GadjahMada University Press.

xxxiv. Ndraha. 1990. Pembangunan Masyarakat: Mepersiapkan Masyarakat Tinggal Landas. Jakarta: Rineka Cipta. NetiSumitro

xxxv. $\quad$ Nur, F. Balkis, S., Naping. H. 2012. Partisipasi Masyarakat dalam Proses pembangunan Infrastruktur Desa; Kasus di KabupatenBulukumba.

xxxvi. Patton, Adri, 2005. Peran Informal Leader Dalam Pembangunan Desa di Daerah Perbatasan Kabupaten Malinau, UniversitasBrawijaya, Malang.

xxxvii. Robert W.(1974)'Employee Motivation and work incentive in service industries' Tersedia pada http://web.1.mseu.msu.edu.com. [Diakses 8 Mei 2008]

xxxviii. Rogers, E. M. And F. F. Shoemaker. 1971. Communication of Innovation. New York. Free Press.

xxxix. Spencer, L.M., and Spencer, S.M. 1983. Competence at Work.New York, Chishter, Brisbane, Toronto, Singapore: John Wiley \& Son Inc.

xl. Sudana, W. dan Kasdi Subagyo. 2015. Pengkajian Penerapan Teknologi Pengolahan Manisan Mangga Kering di Kabupaten Indramayu. Available on ejurnal.litbang.pertanian.go.id/index.php/jpengkajian/article/view/2478 [Accessed 6 November 2017)

xli. Suryono, P. Adisoemarta. 2001. Komunitas Profesional Terbesar di Dunia. Av Accessedailable on https://id.linkedin.com/in/paulus-suryono-adisoemarta-880556114[Diakses 6 November 2017)

xlii. Suryo, Roy. 2013. Kriteria Pemuda. Jakarta: Tribune.

xliii. Undang-Undang Nomor 40 Tahun 2004 tentangKepemudaan

xliv. Wibowo. 2007. Manajemen Kinerja. Jakarta: PT. Raja Grafindo Persada. 
Annexure

\begin{tabular}{|c|c|c|c|c|c|c|c|}
\hline No & Variables & Indicators & Parameters & \multicolumn{4}{|c|}{ Score } \\
\hline \multirow[t]{4}{*}{1} & $\begin{array}{l}\text { Characteristic } \\
\text { respondent }\left(\mathrm{X}_{1}\right)\end{array}$ & Age $\left(X_{11}\right)$ & 1.1.1. Age in the interview session & 1 & 2 & 3 & 4 \\
\hline & & $\begin{array}{l}\text { Training and Education } \\
\left(\mathrm{X}_{12}\right)\end{array}$ & $\begin{array}{ll}\text { 1.2.1. } & \text { Year of education } \\
1.2 .2 . & \text { Length of training }\end{array}$ & $\begin{array}{l}1 \\
1\end{array}$ & $\begin{array}{l}2 \\
2\end{array}$ & $\begin{array}{l}3 \\
3\end{array}$ & $\begin{array}{l}4 \\
4\end{array}$ \\
\hline & & Experience $\left(\mathrm{X}_{13}\right)$ & $\begin{array}{l}\text { 1.3.1 Year of organization's involvement } \\
\text { 1.3.2. Title in organization }\end{array}$ & $\begin{array}{l}1 \\
1\end{array}$ & $\begin{array}{l}2 \\
2\end{array}$ & $\begin{array}{l}3 \\
3\end{array}$ & $\begin{array}{l}4 \\
4\end{array}$ \\
\hline & & $\begin{array}{l}\text { Cosmopolitan/relation } \\
\left(\mathrm{X}_{14}\right)\end{array}$ & $\begin{array}{l}\text { 1.4.1. interaction withentrepreneur } \\
\text { 1.4.2. interaction to the source of innovation }\end{array}$ & $\begin{array}{l}1 \\
1\end{array}$ & $\begin{array}{l}2 \\
2\end{array}$ & $\begin{array}{l}3 \\
3\end{array}$ & $\begin{array}{l}4 \\
4\end{array}$ \\
\hline \multirow[t]{5}{*}{2} & $\begin{array}{l}\text { External } \\
\text { Support }\left(\mathrm{X}_{2}\right)\end{array}$ & $\begin{array}{l}\text { Group } \\
\text { Organization }\left(\mathrm{X}_{21}\right)\end{array}$ & $\begin{array}{l}\text { 2.1.1. Group existence } \\
\text { 2.1.2. Group facility } \\
\text { 2.1.3. Group activity }\end{array}$ & $\begin{array}{l}1 \\
1 \\
1\end{array}$ & $\begin{array}{l}2 \\
2 \\
2\end{array}$ & $\begin{array}{l}3 \\
3 \\
3\end{array}$ & $\begin{array}{l}4 \\
4 \\
4\end{array}$ \\
\hline & & Resource support $\left(\mathrm{X}_{22}\right)$ & $\begin{array}{l}\text { 2.2.1. availability of resources } \\
\text { 2.2.2. availability of capital's sources } \\
\text { 2.2.3. availability of human resources }\end{array}$ & $\begin{array}{l}1 \\
1 \\
1\end{array}$ & $\begin{array}{l}2 \\
2 \\
2\end{array}$ & $\begin{array}{l}3 \\
3 \\
3\end{array}$ & $\begin{array}{l}4 \\
4 \\
4\end{array}$ \\
\hline & & Extension $\left(\mathrm{X}_{23}\right)$ & $\begin{array}{l}\text { 2.3.1. availability of extension } \\
\text { 2.3.2. advocating to extension }\end{array}$ & $\begin{array}{l}1 \\
1\end{array}$ & $\begin{array}{l}2 \\
2\end{array}$ & $\begin{array}{l}3 \\
3\end{array}$ & $\begin{array}{l}4 \\
4\end{array}$ \\
\hline & & $\begin{array}{l}\text { Training opportunity } \\
\left(\mathrm{X}_{24}\right)\end{array}$ & $\begin{array}{l}\text { 2.4.1. legal formal } \\
\text { 2.4.2. program availability }\end{array}$ & $\begin{array}{l}1 \\
1\end{array}$ & $\begin{array}{l}2 \\
2\end{array}$ & $\begin{array}{l}3 \\
3 \\
\end{array}$ & $\begin{array}{l}4 \\
4 \\
\end{array}$ \\
\hline & & Infrastructure $\left(\mathrm{X}_{25}\right)$ & $\begin{array}{l}\text { 2.5.1. Transportation facility } \\
\text { 2.5.2. Meeting facility } \\
\text { 2.5.3. Sport facility }\end{array}$ & $\begin{array}{l}1 \\
1 \\
1\end{array}$ & $\begin{array}{l}2 \\
2 \\
2\end{array}$ & $\begin{array}{l}3 \\
3 \\
3 \\
\end{array}$ & $\begin{array}{l}4 \\
4 \\
4\end{array}$ \\
\hline \multirow[t]{5}{*}{3} & Motivation $\left(\mathrm{X}_{3}\right)$ & $\begin{array}{l}\text { Improved social } \\
\text { relation }\left(\mathrm{X}_{31}\right)\end{array}$ & $\begin{array}{l}\text { 3.1.1. known by a government officer } \\
\text { 3.1.2.relationship with other parties } \\
\text { 3.1.3. helping farmers }\end{array}$ & $\begin{array}{l}1 \\
1 \\
1\end{array}$ & $\begin{array}{l}2 \\
2 \\
2\end{array}$ & $\begin{array}{l}3 \\
3 \\
3\end{array}$ & $\begin{array}{l}4 \\
4 \\
4\end{array}$ \\
\hline & & Award $\left(\mathrm{X}_{32}\right)$ & $\begin{array}{l}\text { 3.2.1. appreciation from government } \\
\text { 3.2.2. importance community } \\
\text { 3.2.3. gain learning opportunity }\end{array}$ & $\begin{array}{l}1 \\
1 \\
1\end{array}$ & $\begin{array}{l}2 \\
2 \\
2\end{array}$ & $\begin{array}{l}3 \\
3 \\
3\end{array}$ & $\begin{array}{l}4 \\
4 \\
4\end{array}$ \\
\hline & & $\begin{array}{l}\text { Willingness for } \\
\text { achievement }\left(\mathrm{X}_{33}\right)\end{array}$ & $\begin{array}{l}\text { 3.3.1. getting achievement } \\
\text { 3.3.2 getting prestige } \\
\text { 3.3.3. willingness to success }\end{array}$ & $\begin{array}{l}1 \\
1 \\
1\end{array}$ & $\begin{array}{l}2 \\
2 \\
2\end{array}$ & $\begin{array}{l}3 \\
3 \\
3\end{array}$ & $\begin{array}{l}4 \\
4 \\
4\end{array}$ \\
\hline & & $\begin{array}{l}\text { Training Opportunity } \\
\left(\mathrm{X}_{34}\right)\end{array}$ & $\begin{array}{l}\text { 3.4.1 getting honor from community } \\
\text { 3.4.2 getting status as a role model } \\
\text { 3.4.3 getting position as a village officer }\end{array}$ & $\begin{array}{l}1 \\
1 \\
1\end{array}$ & $\begin{array}{l}2 \\
2 \\
2\end{array}$ & $\begin{array}{l}3 \\
3 \\
3 \\
\end{array}$ & $\begin{array}{l}4 \\
4 \\
4\end{array}$ \\
\hline & & $\begin{array}{l}\text { Parents suggestion } \\
\left(\mathrm{X}_{35}\right)\end{array}$ & $\begin{array}{l}\text { 3.5.1.parents' support } \\
\text { 3.5.2.No option } \\
\text { 3.5.3.agriculture prospect }\end{array}$ & $\begin{array}{l}1 \\
1 \\
1\end{array}$ & $\begin{array}{l}2 \\
2 \\
2\end{array}$ & $\begin{array}{l}3 \\
3 \\
3\end{array}$ & $\begin{array}{l}4 \\
4 \\
4\end{array}$ \\
\hline \multirow[t]{5}{*}{4} & $\begin{array}{l}\text { Youth } \\
\text { Participation } \\
\text { (Y) }\end{array}$ & $\begin{array}{l}\text { Contribution in } \\
\text { regulation }\left(\mathrm{Y}_{1}\right)\end{array}$ & $\begin{array}{ll}\text { 1.1. } & \text { Giving written comments } \\
\text { 1.2. } & \text { Giving verbal comments }\end{array}$ & $\begin{array}{l}1 \\
1\end{array}$ & $\begin{array}{l}2 \\
2\end{array}$ & $\begin{array}{l}3 \\
3\end{array}$ & $\begin{array}{l}4 \\
4\end{array}$ \\
\hline & & $\begin{array}{l}\text { Assistance in } \\
\text { Program }\left(\mathrm{Y}_{2}\right)\end{array}$ & $\begin{array}{l}\text { 2.1. participation in assisting program } \\
\text { 2.2. role in assisting program }\end{array}$ & $\begin{array}{l}1 \\
1\end{array}$ & $\begin{array}{l}2 \\
2\end{array}$ & $\begin{array}{l}3 \\
3\end{array}$ & $\begin{array}{l}4 \\
4\end{array}$ \\
\hline & & Entrepreneurship $\left(\mathrm{Y}_{3}\right)$ & $\begin{array}{l}\text { 3.1.developing agriculture business } \\
\text { 3.2. having agriculture business }\end{array}$ & $\begin{array}{l}1 \\
1\end{array}$ & $\begin{array}{l}2 \\
2\end{array}$ & $\begin{array}{l}3 \\
3\end{array}$ & $\begin{array}{l}4 \\
4\end{array}$ \\
\hline & & Empowerment $\left(\mathrm{Y}_{4}\right)$ & $\begin{array}{l}\text { 4.1. participation in extension activities } \\
\text { 4.2. Become an extension partner }\end{array}$ & $\begin{array}{l}1 \\
1\end{array}$ & $\begin{array}{l}2 \\
2\end{array}$ & $\begin{array}{l}3 \\
3 \\
\end{array}$ & $\begin{array}{l}4 \\
4 \\
\end{array}$ \\
\hline & & $\begin{array}{l}\text { Advocating Farmers } \\
\left(\mathrm{Y}_{5}\right)\end{array}$ & $\begin{array}{l}\text { 5.1. structured and programmed } \\
\text { 5.2. scope or level activities }\end{array}$ & $\begin{array}{l}1 \\
1\end{array}$ & $\begin{array}{l}2 \\
2 \\
\end{array}$ & $\begin{array}{l}3 \\
3 \\
\end{array}$ & $\begin{array}{l}4 \\
4\end{array}$ \\
\hline
\end{tabular}

Table 7: Indicatorsa Nd Parameters for Each Variable

Individual Characteristic $\left(X_{1}\right)$

- Age

- Level of Education

- Organization experience

\section{Rural Youth Actively Participate In Rural Agricultural Development}

Participation $\left(Y_{1}\right)$

- Contribution in Agriculture Development

- Assistance of Agriculture Development 
- Agriculture entrepreneurship

- Farmer empowerment

- Farmer advocation

External Support $\left(X_{2}\right)$

- Group Organization

- Human Recourse availability

- Resource availability

- Extension

- Infrastructure

Motivation $\left(X_{3}\right)$

- Increased social relation

- Award

- Willingness of achievement

- Training opportunity

- Parents advice

(1) facilitating youth attend training and education, and support youth actively in youth or existing organization

\section{Participation}

- Contributing in development policy.

- Actively assist agriculture development

- Entrepreneurs in agriculture

- Active in farmers' empowerment

- Planner of rural agriculture program

\section{Youth Agriculture Actively Participate In Agricultural Development}

(2) Optimizing farmers group's support in human resource empowerment and maximize natural resource empowerment

(3) Maintaining participation's spirit, opportunity to build relationship, and maintaining unconditional motive to participate 